\title{
PENERAPAN PENDEKATAN KETERAMPILAN PROSES UNTUK MENINGKATKAN HASIL BELAJAR SISWA PADA MATERI ENERGI BUNYI
}

\author{
Sri Cacik, Ulfa Rinayanti \\ PGSD, FKIP, Universitas PGRI Ronggolawe Tuban \\ Email: sricacik@yahoo.co.id
}

\begin{abstract}
Abstrak. Berdasarkan hasil observasi di SDN Ngadirejo II kecamatan Rengel kabupaten Tuban, diketahui bahwa proses pembelajaran masih kurang efektif. Siswa mengalami kesulitan menerima pelajaran IPA pada materi energi bunyi. Hal ini disebabkan oleh beberapa faktor, salah satunya adalah penyampaian materi hanya menggunakan metode ceramah, kesempatan siswa untuk bertanya, menjawab dan menyampaikan pendapat masih kurang, sehingga hasil belajar siswa di bawah KKM. Oleh karena itu peneliti menerapkan pendekatan keterampilan proses untuk meningkatkan hasil belajar siswa kelas. Penelitian ini merupakan Penelitian Tindakan Kelas (PTK) yang setiap siklusnya terdiri dari empat tahapan, yaitu perencanaan, pelaksanaan, pengamatan, dan refleksi. Subjek penelitian adalah siswa kelas IV SDN Ngadirejo II kecamatan Rengel kabupaten Tuban yang berjumlah 21 siswa. Teknik pengumpulan data melalui tes hasil belajar dengan menggunakan instrumen lembar tes hasil belajar. Indikator keberhasilan penelitian diukur dari ketuntasan individual dan klasikal. Hasil penelitian menunjukkan bahwa presentase ketuntasan klasikal meningkat dari $42,85 \%$ pada prapenelitian menjadi $66,67 \%$ pada siklus 1 dan $95,23 \%$ pada siklus 2 . Kendala yang ditemui dalam pelaksanan penelitian adalah guru dan siswa di SDN Ngadirejo II kecamatan Rengel kabupaten Tuban belum terbiasa menggunakan pendekatan keterampilan proses.
\end{abstract}

Kata kunci: Pendekatan keterampilan proses dan hasil belajar

Abstract. Based on observation conducted at SDN Ngadirejo II Rengel Tuban, the researcher found that the learning process is still less effective. The students had difficulty in understanding the science material about the energy of sound. It is caused by several factors, one of which is the informtion transfer just use the direct instruction method, the Students opportunity to develop the skills to ask and submit answers are still lacking, so that student learning outcomes under KKM. Therefore, the researcher applied the science process skills approach to improving classroom student learning outcomes. This research used the Classroom Action Research (CAR) as its design, which is each cycle consists of four phases: planning, implementation, observation, and reflection. the research Subjects were students in the fourth grade in SDN II Ngadirejo Rengel Tuban, which has 21 students. Data collecting technique is done through tests of learning outcomes with achievement test sheet instruments. The indicators of the successfullness of the study are measured through the percentage of individual completeness and classroom. The results showed that the students' learning outcomes increased with the percentage of classical completeness by 42,85\% in prestudy to 66,67\% in the first cycle and 95,23\% in the second cycle. The obstacle encountered in the study was that the teachers and students at SDN Ngadirejo II Rengel Tuban were not used to apply the science process skills approach.

Keywords: Science process skills approach, students' learning outcomes 
PENDAHULUAN

Pendidikan sekolah dasar merupakan bagian dari pendidikan nasional yang mempunyai peranan sangat penting dalam meningkatkan sumber daya manusia, memberikan bekal kemampuan dasar kepada anak seperti pengetahuan dan keterampilan.

Pendidikan juga memainkan peranan yang penting dalam pembangunan dan kemajuan negara dan bangsa. Peranan pendidikan dalam memajukan bangsa yaitu tercermin dalam UU No 20 Tahun 2003 tentang sistem pendidikan nasional. Karena itu, pembaharuan di bidang pendidikan harus terus dilakukan untuk meningkatkan kualitas pendidikan dan mencapai tujuan sistem pendidikan nasional.

Menurut Trianto (2010:17), pembelajaran merupakan aspek kegiatan manusia yang kompleks, yang tidak sepenuhnya dapat dijelaskan. Pembelajaran secara simpel dapat diartikan sebagai produk interaksi berkelanjutan antara pengembangan dan pengalaman hidup. Pembelajaran dalam makna kompleks adalah usaha sadar dari seorang guru untuk membelajarkan siswanya (mengarahkan interaksi siswa dengan sumber belajar lainnya) dalam rangka mencapai tujuan yang diharapkan.

Dalam pembelajaran IPA di Sekolah Dasar guru harus mampu meningkatkan pemahaman siswa, salah satunya adalah dengan metode yang tepat. Salah satu tugas guru adalah menciptakan suasana pembelajaran yang dapat memotivasi siswa untuk senantiasa belajar dengan baik dan semangat. Seorang guru harus memiliki kemampuan dalam memilih pendekatan pembelajaran sekaligus menggunakan metode pembelajaran yang tepat untuk menciptakan situasi belajar yang kondusif (Samatowa, 2006:19).

IPA sebagai ilmu pengetahuan yang aplikatif dalam kehidupan sehari-hari, tidak hanya harus dikuasai dalam bentuk produk (konsep, teori, fakta, hukum), tapi juga dalam bentuk langkah-langkah atau proses kerja ilmiah, sehingga dapat memudahkan siswa dalam memahami konsep pembelajaran.

Upaya yang dapat dilakukan untuk mengembangkan aktifitas siswa dalam pembelajaran, yaitu melalui berbagai pendekatan yang melibatkan emosi dan aktivitas siswa dalam proses pembelajaran IPA, salah satunya yaitu melalui pendekatan keterampilan proses yang menekankan pada cara memperoleh pengetahuan melalui pengalaman belajar secara langsung. Pembelajaran berdasarkan pengalaman menyediakan suatu alternatif pembelajaran bagi siswa yang lebih luas dari pada pembelajaran yang berpusat pada guru. Para siswa akan lebih banyak pengalaman dengan keterlibatan dirinya secara aktif dari pada yang diperoleh dengan melihat atau mendengar suatu konsep. 
Berdasarkan hasil observasi diketahui bahwa hasil belajar siswa kelas IV SDN Ngadirejo II kecamatan Rengel kabupaten Tuban pada mata pelajaran IPA masih rendah. Rata-rata hasil belajar siswa adalah 60,9 sedangkan KKM yang ditentukan oleh sekolah adalah 70. Oleh karena itu, peneliti melakukan penelitian dengan judul "Penerapan Pendekatan Keterampilan Proses Sains untuk Meningkatkan Hasil Belajar Siswa pada Materi Energi Bunyi”.

Tujuan penelitian ini adalah meningkatkan hasil belajar siswa dan mengetahui respon siswa setelah dilakukan kegiatan pembelajaran dengan menggunakan pendekatan keterampilan proses sains pada matere energi bunyi.

Menurut Gulo (2004:8) belajar adalah suatu proses yang berlangsung didalam diri seseorang yang mengubah tingkah laku dalam berfikir, bersikap dan berbuat. Menurut Winataputra (2007:15) belajar merupakan proses yang dilakukan oleh manusia untuk mendapatka aneka ragam kemampuan, keterampilan dan sikap. Rangkaian proses ini dalam bentuk formal, informal, dan non formal.

IPA didefinisikan sebagai kumpulan pengetahuan yang tersusun secara terbimbing. Hal ini dengan kurikulum KTSP (Depdiknas, 2006) bahwa "IPA berhubungan dengan cara mencari tahu tentang alam secara sistematis, sehingga bukan hanya penguasaan kumpulan pengetahuan yang berupa fakta, konsep, atau prinsip saja tetapi juga merupakan suatu proses penemuan”. Selain itu IPA juga merupakan ilmu yang bersifat empirik dan membahas tentang fakta serta gejala alam. Fakta dan gejala alam tersebut menjadikan pembelajaran IPA tidak hanya verbal tetapi juga faktual. Hakikat IPA sebagai proses diwujudkan dengan melaksanakan pembelajaran yang melatih keterampilan proses bagaimana cara produk sains ditemukan. Muslichah (2006:22) menyatakan bahwa keterampilan proses yang perlu dilatih dalam pembelajaran IPA meliputi keterampilan proses dasar misalnya mengamati, mengukur, mengklasifikasikan, mengkomunikasikan, mengenal hubungan ruang dan waktu, serta keterampilan proses terintegrasi misalnya merancang dan melakukan eksperimen yang meliputi menyusun hipotesis, menentukan variabel, menyusun definisi operasional, menafsirkan data, menganalisis dan mensintesis data.

Poedjiati (2005:78) menyebutkan bahwa keterampilan dasar dalam pendekatan proses adalah observasi, menghitung, mengukur, mengklasifikasi, dan membuat hipotesis. Sehingga dapat disimpulkan bahwa keterampilan proses dalam pembelajaran IPA di SD meliputi keterampilan dasar dan keterampilan terintegrasi.

Kedua keterampilan dapat melatih siswa untuk menemukan dan menyelesaikan masalah secara ilmiah untuk menghasilkan 
produk-produk IPA yaitu fakta, konsep generalisasi, hukum, dan teori-teori baru.

Pendekatan keterampilan proses merupakan pendekatan belajar mengajar yang mengarah kepada pengembangan kemampuan mental, fisik dan sosial yang mendasar sebagai penggerak kemampuan yang lebih tinggi dalam diri individu siswa. Pendekatan keterampilan proses sebagai pendekatan yang menekan pada pertumbuhan dan pengembangan sejumlah keterampilan tertentu pada diri peserta didik agar mereka mampu memproses informasi sehingga ditemukan hasil-hasil yang baru yang bermanfaat baik berupa fakta, konsep, maupun pengembangan sikap dan nilai. Pembelajaran menggunakan keterampilan proses adalah proses pembelajaran yang dirancang sedemikian rupa sehingga siswa dapat menemukan fakta-fakta, membangun konsep-konsep dan teori-teori dengan menggunakan keterampilan proses dan sikap ilmiah siswa sendiri (Soetardjo, 1998:3). Dalam pendekatan keterampilan proses tugas guru adalah memberikan kemudahan kepada peserta didik dalam menciptakan lingkungan yang kondusif agar semua peserta didik dapat berkembang secara optimal. Jadi dapat disimpulkan bahwa keterampilan proses adalah sebuah sebuah pembelajaran yang menekankan pada proses belajar sehingga siswa dapat menemukan fakta-fakta yang terjadi.

Pembelajaran dengan pendekatan keterampilan proses sains mengikuti langkah-langkah sebagai berikut:

Tabel 1. Langkah-langkah Pembelajaran dengan Keterampilan Proses Sains

\begin{tabular}{|c|c|c|}
\hline No & Langkah & Keterangan \\
\hline 1 & Observasi & $\begin{array}{l}\text { Siswa mengumpulkan data dengan } \\
\text { menggunakan alat indera selama } \\
\text { percobaan berlangsung. }\end{array}$ \\
\hline 2 & $\begin{array}{l}\text { Menggolong } \\
\text { kan }\end{array}$ & $\begin{array}{l}\text { Siswa mempersiapkan bahan apa } \\
\text { saja yang harus digunakan selama } \\
\text { percobaan yang digunakan dalam } \\
\text { percobaan }\end{array}$ \\
\hline 3 & Menafsirkan & $\begin{array}{l}\text { Siswa mencatat hal-hal penting dan } \\
\text { mengemukakan pemahaman } \\
\text { selama percobaan. }\end{array}$ \\
\hline 4 & Meramalkan & $\begin{array}{l}\text { Siswa meramalkan kemungkinan } \\
\text { yang akan terjadi dari kegiatan } \\
\text { menafsirkan yang telah dilakkan. }\end{array}$ \\
\hline
\end{tabular}

Menurut Winarno, (2012:138) hasil belajar jika dilihat dari sisi siswa merupakan belajar merupakan hal yang dapat di pandang tingkat perkembangan mental yang lebih dari dua sisi yaitu sisi siswa dan guru. Hasil baik bila dibandingkan pada saat sebelum 
belajar. Tingkat perkembangan mental terwujud pada ranah kognitif, afektif, dan psikomotor. Sedangkan dari sisi guru, hasil belajar merupakan saat terselesaikannya bahan pelajaran. Proses penilaian terhadap hasil belajar dapat memberikan informasi kepada guru tentang kemampuan siswa dalam upaya mencapai tujuan pembelajaran. Hasil belajar dipengaruhi oleh dua faktor yaitu faktor internal dan faktor eksternal. Faktor internal adalah faktor yang bersumber dari dalam diri siswa. Faktor internal meliputi kecerdasan, minat, motivasi belajar, ketekunan, sikap, kebiasaan belajar, serta kondisi fisik dan kesehatan. Sedangan faktor eksternal adalah faktor yang berasal dari luar diri siswa yang yaitu keluarga, sekolah dan masyarakat. Hasil belajar siswa yang dimaksudkan dalam penelitian ini merupakan pengetahuan yang dicapai siswa setelah mengalami proses pembelajaran yang diketahui dari hasil tes atau ujian yang diberikan setelah melewati proses belajar menggunakan pendekatan keterampilan proses sains.

\section{METODE}

Penelitian ini merupakan penelitian tindakan kelas (PTK) yang modelnya dikembangkan oleh Kemmis dan McTaggart (dalam Tampubolon, 2014: 155). Metode ini meliputi serangkaian siklus yang saling terkait. Setiap siklus mencakup empat tahapan, yaitu perencanaan, pelaksanaan, observasi, dan refleksi.

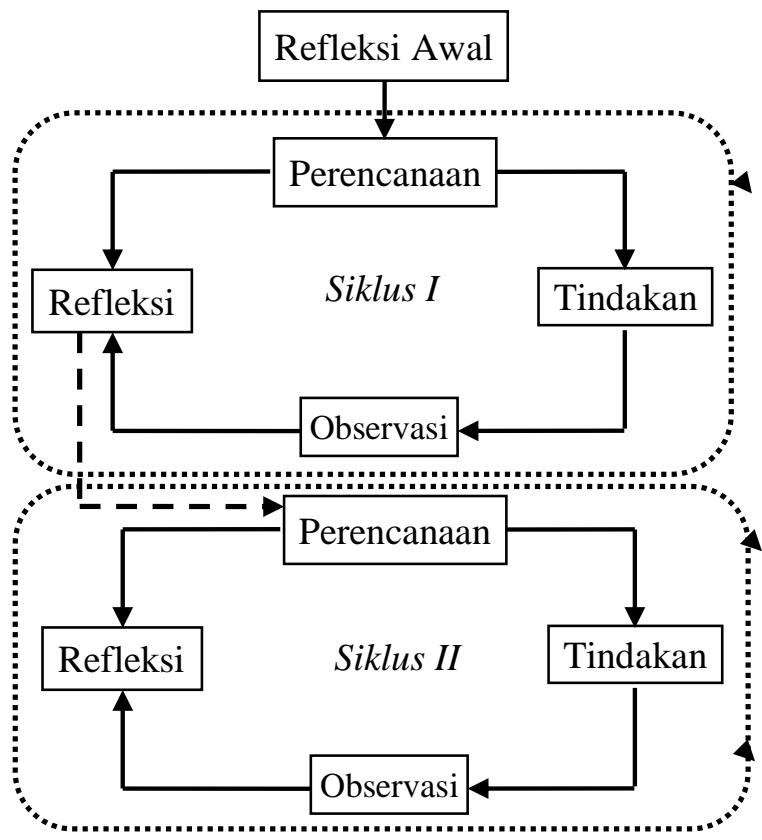

Gambar 1. Desain siklus PTK

Lokasi penelitian dilaksanakan di SDN Ngadirejo II kecamatan Rengel kabupaten Tuban tahun pelajaran 2015/2016. Waktu penelitian dilaksanakan pada semester II tahun pelajaran 2015/2016 mulai bulan April 2016 sampai dengan bulan Mei 2016. Subyek penelitian adalah siswa kelas IV semester genap SDN Ngadirejo II kecamatan Rengel kabupaten Tuban yang berjumlah 21 siswa terdiri dari 10 laki-laki dan 11 perempuan.

Instrumen yang digunakan dalam penelitian ini adalah silabus, RPP, lembar tes hasil belajar, dan angket. Data hasil penelitian dianalisis menggunakan teknik analisis ketuntasan individual dan klasikal.

Presentase ketuntasan belajar siswa secara klasikal digunakan rumus: 


$$
K B=\frac{\text { jumlah Siswa Tuntas }}{\text { jumlah Siswa }} X 100 \%
$$

(Mulyasa, 2003: 102)

Keterangan:

$\mathrm{KB}=$ Ketuntasan Belajar

Siswa nyatakan tuntas apabila dapat mencapai KKM yang telah ditetapkan sekolah yaitu 70. Sedangkan ketuntasan belajar siswa secara klasikal tercapai apabila mendapat skor minimal $80 \%$.

Pada siklus I dilakukan pembelajaran dengan materi sumber bunyi. Apabila hasil observasi menunjukkan bahwa ketuntasan belajar siswa secara klasikal belum memenuhi kreteria ketuntasan klasikal minimal maka peneliti akan melanjutkan ke siklus berikutnya yaitu siklus II. Pada siklus II materi yang disampaikan adalah sifat-sifat bunyi. Kekurangan-kurangan proses belajar mengajar yang ditemukan pada siklus I tahap refleksi akan menjadi bahan pertimbangan untuk perbaikan siklus II.

Data respon siswa yang diperoleh dianalisis deskriptif dengan langkah menyusun hasil angket dan mengubah frekuensi ke dalam presentase dengan rumus sebagai berikut:

$$
P=\frac{f}{n} 100 \% \quad \text { (Setyo, 2006:85) }
$$

Keterangan:

$\mathrm{P}=$ Prosentase responden

$\mathrm{f} \quad=$ Banyaknya responden setuju

$\mathrm{n}$ = Banyaknya responden

\section{HASIL DAN PEMBAHASAN}

Sebelum melaksanakan penelitian, peneliti mengumpulkan data dan informasi dengan kegiatan prasiklus. Data hasil prasiklus menunjukkan bahwa nilai rata-rata hasil belajar siswa adalah 60,9. Data yang diperoleh menunjukkan bahwa hanya $42,85 \%$ siswa dapat mencapai KKM. Hal tersebut menunjukkan bahwa ketuntasan klasikal belum tercapai. Oleh karena itu kegiatan pembelajaran harus diperbaiki. Salah satu pendekatan pembelajaran yang dapat digunakan dalam pembelajaran IPA menurut peneliti adalah pendekatan keterampilan proses sais yang akan dilaksanakan pada siklus I.

Pada siklus I peneliti menerapkan pendekatan keterampilan proses pada materi sumber energi bunyi beserta contoh sumber energi bunyi. Setelah siswa mengikuti proses pembelajaran, peneliti memberikan tes tertulis berupa soal pilihan ganda dengan jumlah soal sepuluh yang telah divalidasi oleh ahli. Hal ini dilakukan untuk mengetahui hasil belajar siswa. Berikut ini data hasil belajar siswa siklus I. 
Tabel 2. Hasil Belajar Siklus I



Berdasarkan Tabel 2 diketahui bahwa nilai rata-rata kelas 67,14. Nilai tertinggi yang dapat dicapai siswa adalah 80, sedangkan nilai terendah adalah 50. Dari 21 siswa, 14 (67,7\%) siswa dinyatakan tuntas dan $11(33,3 \%)$ siswa belum tuntas. Hasil tersebut menunjukkan bahwa pada siklus I ketuntasan klasikal masih belum tercapai, karena presentase siswa yang tuntas adalah 67,7\%, namun hasil belajar siswa sudah meningkat dari pra siklus ke siklus 1 . Penerapan pendekatan keterampilan proses cukup baik, tetapi belum optimal karena siswa belum terbiasa menggunakan pendekatan keterampilan proses. Motivasi siswa masih rendah, antusias guru dan siswa masih rendah, pengelolaan waktu juga masih kurang baik, dan kerjasama diantara siswa masih belum terjalin dengan baik. Oleh karena itu, peneliti melakukan refleksi dan perbaikan pada siklus ke II. Perbaikan yang dilakukan pada siklus II adalah mengorganisasikan waktu secara optimal, membimbing siswa secara optimal, dan merencanakan kegiatan pembelajaran dengan lebih terencana. Hasil belajar siswa siklus II adalah: 
Tabel 3. Hasil Belajar Siklus II

\begin{tabular}{|c|c|c|c|c|c|}
\hline \multirow{2}{*}{ No } & \multirow{2}{*}{ Siswa } & \multirow{2}{*}{ KKM } & \multirow{2}{*}{ Nilai } & \multicolumn{2}{|c|}{ Ketuntasan } \\
\hline & & & & $\mathbf{T}$ & BT \\
\hline 1 & $\mathrm{~S} 1$ & 70 & 80 & $\sqrt{ }$ & \\
\hline 2 & $\mathrm{~S} 2$ & 70 & 80 & $\sqrt{ }$ & \\
\hline 3 & S3 & 70 & 70 & $\sqrt{ }$ & \\
\hline 4 & S4 & 70 & 80 & $\sqrt{ }$ & \\
\hline 5 & S5 & 70 & 80 & $\sqrt{ }$ & \\
\hline 6 & S6 & 70 & 70 & $\sqrt{ }$ & \\
\hline 7 & S7 & 70 & 80 & $\sqrt{ }$ & \\
\hline 8 & S8 & 70 & 70 & $\sqrt{ }$ & \\
\hline 9 & S9 & 70 & 70 & $\sqrt{ }$ & \\
\hline 10 & S10 & 70 & 60 & & $\sqrt{ }$ \\
\hline 11 & $\mathrm{~S} 11$ & 70 & 80 & $\sqrt{ }$ & \\
\hline 12 & $\mathrm{~S} 12$ & 70 & 80 & $\sqrt{ }$ & \\
\hline 13 & S13 & 70 & 70 & $\sqrt{ }$ & \\
\hline 14 & S14 & 70 & 70 & $\sqrt{ }$ & \\
\hline 15 & $\mathrm{~S} 15$ & 70 & 80 & $\sqrt{ }$ & \\
\hline 16 & S16 & 70 & 70 & $\sqrt{ }$ & \\
\hline 17 & S17 & 70 & 70 & $\sqrt{ }$ & \\
\hline 18 & S18 & 70 & 90 & $\sqrt{ }$ & \\
\hline 19 & S19 & 70 & 70 & $\sqrt{ }$ & \\
\hline 20 & $\mathrm{~S} 20$ & 70 & 70 & $\sqrt{ }$ & \\
\hline 21 & $\mathrm{~S} 21$ & 70 & 80 & $\sqrt{ }$ & \\
\hline \multicolumn{2}{|c|}{ Jumlah } & 70 & 1570 & 20 & 1 \\
\hline \multicolumn{2}{|c|}{ Rata-rata } & & 74,76 & 20 & $\mathbf{1}$ \\
\hline \multicolumn{4}{|c|}{ Prosentase $(\%)$} & $95,2 \%$ & $4,8 \%$ \\
\hline
\end{tabular}

Berdasarkan Tabel 3 diketahui bahwa nilai rata-rata kelas 74,76. Dari 21 siswa, 20 siswa atau 95,2\% mencapai KKM sedangkan 1 siswa atau 4,8\% belum mencapai KKM. Sehingga bisa dikatakan bahwa ketuntasan klasikal tercapai. Ketercapaian ketuntasan hasil belajar siklus I dan siklus II digambarkan dalam diagram batang Gambar 1.



Gambar 2. Diagram Ketuntasan Klasikal

Berdasarkan diagram pada Gambar 2, siklus I dan siklus II mengalami peningkatan diketahui bahwa hasil belajar siswa pada artinya bahwa penerapan pendekatan 
keterampilan proses pada materi energi bunyi dapat meningkatkan hasil belajar. Hasil belajar siswa dapat meningkat karena siswa mempelajari konsep energi bunyi dengan memberikan kesempatan kepada siswa untuk terlibat langsung dalam proses pembelajaran, siswa menemukan konsep sendiri menemukan fakta-fakta, membangun konsep-konsep dan teori-teori. Hal ini sesuai dengan teori yang dikemukan oleh (Soetardjo, 1998:3).

Hasil angket respon siswa setelah diterapkan pendekatan keterampilan proses menunjukkan bahwa $90,5 \%$ siswa memberikan respon positif dan tertarik terhadap kegiatan pembelajaran dengan menerapkan keterampilan proses.

\section{SIMPULAN}

Berdasarkan hasil penelitian dan pembahasan yang diperoleh dari penerapan pendekatan keterampilan proses pada materi energi bunyi di kelas IV SDN Ngadirejo kecamatan Rengel kabupaten Tuban dapat disimpulkan bahwa penerapan pendekatan keterampilan proses dapat meningkatkan hasil belajar siswa. Pada siklus I rata-rata hasil belajar sebesar 67,14 dengan ketuntasan klasikal $66,7 \%$, dan pada siklus II rata-rata hasil belajar sebesar 74,76 dengan ketuntasan klasikal 95,2\%. Siswa memberikan respon positif dan tertarik mengikuti pembelajaran dengan pendekatan keterampilan proses.

\section{DAFTAR PUSTAKA}

Depdiknas. 2006. Kurikulum Satuan Tingkat Pendidikan (KTSP). Jakarta: Departemen Pendidikan Nasional.

Gulo, W. 2004. Strategi Belajar Mengajar. Jakarta: PT Grasindo.

Mulyasa. E. 2003. Kurikulum Berbasis Kompetens;Konsep, Karakteristik dan Implementasi. Bandung: PT Remaja Rosda Karya.

Muslichah, A. 2006. Penerapan SainsTeknologi-Masyarakat dalam Pembelajaran Sains di Sekolah Dasar. Jakarta: Depdiknas.

Poedjiati. 2005. Hakekat Pembelajaran IPA. (http://www.sekolahdasar.net/ 2011 /05/hakekat-pembelajaran-ipa-disekolah.html). Diakses 14 Juni 2013.

Samatowa, U. 2006. Bagaimana Membelajarkan IPA di Sekolah Dasar.

Setyo, R. 2006. Metodoloi Penelitian. Bandung: Politeknik Pos Indonesia.

Soetardjo. 1998. Proses Belajar Mengajar dengan Metode Pendekatan Keterampilan Proses. Surabaya: SIC.

Tampubolon, S. 2014. Penelitian Tindakan Kelas Sebagai Pengembangan Profesi Pendidik dan Keilmuan. Jakarta: Erlangga.

Trianto. 2010. Mendesain Model Pembelajaran Inovatif-Progesif. Jakarta: Kencana.

Winarno. 2012. Kebijakan Publik, Teori, Proses, dan Studi Kasus edisi \& Revisi Terbaru. Jogjakarta: CAPS.

Winataputra, U. S. 2007. Teori Belajar dan Pembelajaran. Jakarta: Universitas Terbuka. 